\title{
GROSS ALPHA/BETA RADIOACTIVITY IN DRINKING WATER IN THE MAIN CITIES OF ALBANIA
}

\author{
Florinda Cfarku $^{1 *}$, Manjola Shyti ${ }^{1}$, Erjon Spahiu $^{2}$ \\ 1*Institute of Applied Nuclear Physics, University of Tirana, P.O.Box 85. Tirana, Albania; \\ ${ }^{2}$ Department of Physics, Faculty of Natural Sciences, University of Tirana, Blv. Zogu I, Tirana, Albania; \\ *Corresponding author Florinda Cfarku, e-mail: fcfarku@yahoo.com;
}

Received November 2019; Accepted December 2019; Published January 2020;

DOI: https://doi.org/10.31407/ijees10.110

\begin{abstract}
The main sources of radioactivity in drinking-water are: the leaching of radionuclides from rocks and soils and the deposition of radionuclides from the atmosphere. Naturally occurring radionuclides from both these sources account for almost the entire radioactivity present in Albanian drinking water. The principal responsible radionuclides in drinking water are ${ }^{238} \mathrm{U},{ }^{232} \mathrm{Th},{ }^{40} \mathrm{~K}$ and, to a lesser extent, trace elements, such as ${ }^{235} \mathrm{U}$. Alpha-emitting radioelements are ${ }^{226} \mathrm{Ra},{ }^{224} \mathrm{Ra},{ }^{210} \mathrm{Po}$ and in certain circumstances, the uranium isotopes ${ }^{234} \mathrm{U}$ and ${ }^{235} \mathrm{U}$, as they are rather insoluble in reducing environments but are soluble in oxidizing and particularly in acidic conditions. As a consequence the control of natural radionuclides in water for human consumption has become a major goal worldwide during the recent decade. Limitations were set and the need for simple and rapid procedures for their implementation becomes necessary. As a consequence of the ICRP 65 recommendations the European Community in their directives 98/83 EC in 1998 demands for the control of radioactivity levels in water for human consumption. This has been extended in 2001 as well to Radon and long lived daughter nuclides. As a consequence the member states are enforced to transfer these directives into national legislation. An action level of $0.1 \mathrm{mSv} / \mathrm{a}$ for total natural radiation exposure from drinking water has been fixed (Council Directive 98/83/EC). According to Albanian legislation Nr.957, date 25. 11. 2015 "Guide levels of indoor radon concentration and radioactivity concentration in goods, with effect public protection", article 6 "Guidance levels for radionuclide concentration in water intended for public consumption" the gross alpha/beta screening was first carried out since it is a simple radioanalytical procedure, without regard to the identity of specific radionuclides. For gross alpha and gross beta radioactivity concentration exceeding the screening levels of $0.5 \mathrm{~Bq} / \mathrm{L}$ and $1 \mathrm{~Bq} / \mathrm{L}$ respectively, the further investigation is needed.
\end{abstract}

Keywords: Gross alpha/beta, Drinking water sample, Surface contamination 